\title{
A Spatial Study of Geo-Economic Risk Exposure of Russia's Arctic Mono-Towns with Commodity Export-Based Economy
}

\author{
Anatoly Anokhin ${ }^{1}$, Sergey Kuznetsov ${ }^{2}$ \& Stanislav Lachininskii ${ }^{1}$ \\ ${ }^{1}$ Department of Economic \& Social Geography, Saint-Petersburg State University, Saint-Petersburg, Russia \\ ${ }^{2}$ Institute of Regional Economy of RAS, Russian Academy of Science, Saint-Petersburg, Russia \\ Correspondence: Stanislav Lachininskii, Department of Economic \& Social Geography, Saint-Petersburg State \\ University, Saint-Petersburg, Russia. Tel: 7-812-323-4089. E-mail: lachininsky@gmail.com
}

\author{
Received: December 30, 2013 Accepted: January 14, 2014 Online Published: January 16, 2014 \\ doi:10.5539/jgg.v6n1p38 \\ URL: http://dx.doi.org/10.5539/jgg.v6n1p38
}

\begin{abstract}
In the context of stagnating global economy mono-towns of Arctic Russia are especially exposed to uncertainty in their socio-economic development. Resource orientation of economy that formed in the 20th century entails considerable geo-economical risk exposure both for the towns and their population as well as for Russia's specific regions. In the 1990-2000s Russia's Arctic regions were exposed to a systemic crisis which stemmed from production decline, out-migration, capital asset obsolescence, depletion of mineral resources and environmental crisis.

This spatial study of geo-economic risk exposure of Russia's Arctic mono-towns with commodity export-based economy was conducted at four dimensions - global, macro-regional, regional and local. The study of the five types of geo-economic risks was based on the existing approach, economic and socio-demographic risks being the most critical for the towns under consideration. Survey data will be used as the basis for recommendations related to prevention of potential jeopardies for the mono-towns of the region under consideration. The findings of this study will be included in the materials of survey N12-32-06001 "Russia's Arctic Regional a Contemporary Model of Sustainable Development" funded by Russian Fund for Humanities Studies.
\end{abstract}

Keywords: mono-towns, Russia’s Arctic regions, geo-economic risks, spatial study

\section{Introduction}

This study is focused on geo-economic risk exposure of Russia's Arctic mono-towns with commodity export-based economy.

The circumpolar Arctic macro region plays a key environmental, transportation and economic role both at the national and worldwide level. Sustainable socio-economic development of Arctic regions, infrastructure development, including transportation facilities, environmental safety and military security, national border protection, international humanitarian cooperation and indigenous minorities habitation in the circumpolar Arctic region are becoming increasingly critical (Strategy, 2013). This Strategy was design by geo-economists and regional studies experts (Pilyasov, 2010, 2011). Concurrently with Russia's Arctic regional development strategy the UK Arctic policy framework was published, yet it is rather focused on environmental protection aspects (Depledge, 2013).

It was through fundamental study and knowledge of Arctic specifics that experts were able to propose a relevant agenda for Russia's Arctic regions. It is worth noting that many of the theses of this Strategy stem from the positive experience of the Soviet Union and key Arctic economies, including Canada.

In the 1930s-1970s, a number of mining industry support centers were set up in the Arctic regions, which contributed to the development of the prolific regional mineral resources. However, by the 1990s, such towns degraded into areas of permanent socio-environmental and economic instability, which was caused primarily by continuous mechanical out-migration and deterioration of life level and quality in such towns. However, today they remain key components of urban skeleton of this region. These towns play the role of local coordination centers for the exploration and sustainable development of the adjacent areas.

At the same time, Arctic and Siberian mono-towns have developed into channels for globalization trends that 
project on the socio-economic development of Russia's regions. "Globalization impact on Russia's regions and national territorial structure has been exceptionally contradictory. On the one hand, globalization processes, being one of the key drivers of economic growth (and decline) and an incentive to industrial innovation and regional/local investment attractions, have an extremely unbalanced impact on the national territory and lead to further polarization of socio-economic environment and social conflicts" (Artobolevsky et al., 2009).

Today 335 mono-towns with 15.8 million aggregate population exist in Russia. This means that every ninth Russian lives in a mono-town. Mono-towns are towns with over $25 \%$ population employed at a single company or group of companies belonging to the same industry. Such a large number of mono-towns in Russia is the effect of accelerated industrialization in the 20th century when over $30 \%$ of towns were built in the Soviet period of industrial development.

"Mono-towns are an essential attribute of regional economic environment of industrial and extractive regions in many economies at a certain phase of their economic development where the industrial sector constitutes a key factor of urban development" (Conceptual Approaches, 2010).

Mono-towns exist both in advanced economies, such as US, UK, Germany, Canada, France, and Australia, and in transitional economies, such as China, Mexico, Brazil, and India. However, the development patterns and opportunities of such mono-towns differ significantly. Development patterns are predicated upon sustainability of municipal economy, existence of an advanced MSE sector and the extent of state responsibility. In strong market economies (US, UK, Canada) the development opportunities of such mono-towns are limited to a certain extent. These limitations stem from the fact that advanced market mechanisms promote mobility and migration of the population.

In certain European economies with a strong role of socio-democratic traditions and public integrity, mono-town development opportunities are related to scaled restructuring of old industrial businesses, implementation of substituting processes and R\&D promotion.

In transitional economies such mono-towns are traditionally supported by public subsidies.

18 Russian mono-towns are located in the Arctic region. 12 of them, i.e. Monchegorsk, Kovdor, Nikel, Revda, Kirovsk, Vorkuta, Inta, Gubkinsky, Nadym, Noyabrsk, Norilsk and Novy Urengoy, are resource-based industrial centers. These mono-towns include non-ferrous metal ore mining and processing facilities (Monchegorsk, Nikel, Revda and Norilsk), mineral mining facilities (Kovdor and Kirovsk), hard coal mining (Vorkuta and Inta), and hydrocarbon (oil and gas) development (Noyabrsk, Nadym, Gubkinsky and Novy Urengoy).

Generally until 1989 the population of these mono-towns constantly increased both naturally due to natural factors, such as favourable age-sex population pattern and high content of able-bodied population, and mechanical factors, which included mandatory job assignment for university graduates and the so-called young communist construction projects from the 1940s through the 1980s (Revda, Apatity, Kovdor etc.).

\section{Methods and Results}

Statistical analysis of the demographic trend of these mono-towns from 1989 through 2010 has shown that in the contest of production decline caused by denationalization of property, management disorganisation and value chain disruption the population of these mono-towns shrank from 865.7 to 676.1 thousand people, i.e. by $21.9 \%$.

The most significant demographic reduction was recorded in the towns that were developed at an earlier industrialization phase, i.e. Inta, Nikel, Revda and Vorkuta, as well as in Kirovsk and Monchegorsk (see Table 1).

The most complicated situation has formed in Murmansk region and Komi Republic.

The factors that led to population decline in such mono-towns include: production decline caused by economic crisis and, accordingly, layoffs, birth rate decrease and out-migration that were induced by change in polar employment benefit policy, downsizing and unavailability of social infrastructure facilities, social life standard deterioration etc.

Until late 1980s Murmansk region was rated as the most dynamic demographic growth leader among all European North regions, and a runner-up in industrial production among Russia's European regions. Between 1926 and 1991 the population of Murmansk region increased 36.3 times (Kola Encyclopaedia, 2013) with absolute domination of urban population, yet by early 21 st century the region faced out-migration and depopulation. The region's current safety margin is based on the age structure of its population, with able-bodied population content $7 \%$ higher than the national average and senior population content $7 \%$ lower than the national average. However, proper allowance must be made for the fact that the 
sever climate of Murmansk and other Arctic regions enhances "heliotropism", i.e. the tendency of retired population to relocate permanently to southern regions with more favourable climate (Krasnodar, Voronezh, Belgorod, Rostov and other regions).

Table 1. Russia's Arctic commodity export-based mono-towns in 1989-2010

\begin{tabular}{|c|c|c|c|c|}
\hline Mono-town & $\begin{array}{l}\text { Population, } \\
\text { thousand people } \\
\text { (1989) }\end{array}$ & $\begin{array}{l}\text { Population, } \\
\text { thousand people } \\
(2010)\end{array}$ & Specialization & $\begin{array}{l}\text { Population } \\
\text { change }\end{array}$ \\
\hline Norilsk & 267,3 & 175.4 & $\begin{array}{l}\text { Non-ferrous metallurgy } \\
\text { (Norilsky nickel) }\end{array}$ & $-34,1 \%$ \\
\hline Noyabrsk & 87.1 & 110.6 & $\begin{array}{l}\text { Gas production } \\
\text { (Gazprom) }\end{array}$ & $+27.0 \%$ \\
\hline Novy Urengoy & 95.3 & 104.1 & $\begin{array}{l}\text { Gas production } \\
\text { (Gazprom) }\end{array}$ & $+9.2 \%$ \\
\hline Vorkuta & 115.3 & 70.5 & $\begin{array}{l}\text { Coal mining } \\
\text { (Severstal) }\end{array}$ & $-38.8 \%$ \\
\hline Nadym & 52.6 & 46.6 & $\begin{array}{l}\text { Gas production } \\
\text { (Gazprom) }\end{array}$ & $-11.4 \%$ \\
\hline Monchegorsk & 68.6 & 45.3 & $\begin{array}{l}\text { Non-ferrous metallurgy } \\
\text { (Norilsky nickel) }\end{array}$ & $-34.0 \%$ \\
\hline Inta & 60.2 & 32.1 & $\begin{array}{l}\text { Coal mining } \\
\text { (Inta Coalmine) }\end{array}$ & $-46.7 \%$ \\
\hline Kirovsk & 43.5 & 28.6 & $\begin{array}{l}\text { Chemical industry } \\
\text { (Fosagro) }\end{array}$ & $-34.2 \%$ \\
\hline Gubkinsky & 9.7 & 23.3 & $\begin{array}{l}\text { Gas production } \\
\text { (Gazprom) }\end{array}$ & $+140.2 \%$ \\
\hline Kovdor & 30.5 & 18.8 & $\begin{array}{l}\text { Chemical industry } \\
\text { (Eurochem) }\end{array}$ & $-38.4 \%$ \\
\hline Nikel & 21.8 & 12.4 & $\begin{array}{l}\text { Non-ferrous metallurgy } \\
\text { (Norilsky nickel) }\end{array}$ & $-43.1 \%$ \\
\hline Revda & 13.8 & 8.4 & $\begin{array}{l}\text { Non-ferrous metallurgy } \\
\text { (Lovozersky Plant) }\end{array}$ & $-39.1 \%$ \\
\hline Total & 865.7 & 676.1 & & $-21.9 \%$ \\
\hline
\end{tabular}

The most complicated situation has formed in Murmansk region and Komi Republic.

The factors that led to population decline in such mono-towns include: production decline caused by economic crisis and, accordingly, layoffs, birth rate decrease and out-migration that were induced by change in polar employment benefit policy, downsizing and unavailability of social infrastructure facilities, social life standard deterioration etc.

Until late 1980s Murmansk region was rated as the most dynamic demographic growth leader among all European North regions, and a runner-up in industrial production among Russia's European regions. Between 1926 and 1991 the population of Murmansk region increased 36.3 times (Kola Encyclopaedia, 2013) with absolute domination of urban population, yet by early 21 st century the region faced out-migration and depopulation. The region's current safety margin is based on the age structure of its population, with able-bodied population content $7 \%$ higher than the national average and senior population content $7 \%$ lower than the national average. However, proper allowance must be made for the fact that the sever climate of Murmansk and other Arctic regions enhances "heliotropism", i.e. the tendency of retired population to relocate permanently to 
southern regions with more favourable climate (Krasnodar, Voronezh, Belgorod, Rostov and other regions).

The Strategy reasonably points out that "Russia's Arctic regions clearly fall into two categories: rent type regions with high-value natural resources that generate significant economic rent flows, and transfer-based regions whose budget income consists primarily of transfers allocated from the federal budget" (Strategy, 2013).

However, both categories, i.e. rent and transfer, are applicable to the mono-towns under discussion. Per capita transfer allocation rating has shown that the rating for Murmansk region is 1.15 , while for Komi Republic it is 0.73 (see Table 2).

Generally speaking, only three Arctic regions-Komi, Yamalo-Nenets autonomous district and Krasnoyarsk Krai (due to Taymyr municipal district), belong to rent type. Nenets autonomous district can be included into the rent category, yet administratively this region is included in Arkhangelsk region for inter-budgetary transfer allocation purposes.

Table 2. Rent and transfer funds of Russia's Arctic regions in 2009-2013

\begin{tabular}{lllll}
\hline \multirow{2}{*}{ Region } & \multicolumn{2}{c}{2009} & \multicolumn{2}{c}{2013} \\
\cline { 2 - 5 } & $\begin{array}{l}\text { Transfer funds } \\
\text { RUR mio }\end{array}$ & $\begin{array}{l}\text { Per capita, } \\
\text { RUR/per capita transfer } \\
\text { allocation rating }\end{array}$ & $\begin{array}{l}\text { Transfer funds } \\
\text { RUR mio }\end{array}$ & $\begin{array}{l}\text { Per capita, } \\
\text { RUR/per capita transfer } \\
\text { Karelia }\end{array}$ \\
\cline { 2 - 5 } $\begin{array}{l}\text { Arkhangelsk } \\
\text { region }\end{array}$ & 3558 & $5562,0 / 1,04$ & 4731 & $7397,0 / 1,42$ \\
Murmansk region & 70077 & $8304,0 / 1,55$ & 10019 & $8333,0 / 1,60$ \\
Komi & 4582 & $8893,0 / 1,66$ & 4673 & $5988,0 / 1,15$ \\
YNAD & 1625 & $5149,0 / 0,96$ & 3355 & $3809,0 / 0,73$ \\
Krasnoyarsk Krai & 10933 & $3028,0 / 0,56$ & 967 & $1785,0 / 0,34$ \\
Yakutia & 39440 & $3852,0 / 0,72$ & 10034 & $3535,0 / 0,68$ \\
Chukotka & 4174 & $41261,0 / 7,70$ & 55754 & $58344,0 / 11,18$ \\
National total & $\mathbf{7 6 6 5 9 3}$ & $\mathbf{5 3 6 1 , 0 / 1 , 0 0}$ & 595 & $11712,0 / 2,24$ \\
\hline
\end{tabular}

Note: 1 USD $=31$ RUR.

To this extent a key fundamental problem of geo-economic study and geo-economic risk exposure assessment approaches for Russia's Arctic mono-town with commodity export-based economy arises.

We shall review the geo-economic risk exposure of Russia's Arctic mono-towns at the inferior local level (Lachininskii, 2013). This stratification level includes both cities/towns and industrial facilities as well as unique deposits of mineral resources and global infrastructure facilities. In this case a specific correlation exists: mineral resource deposit - industrial facility/geo-economic agent - mono-town. The following examples may be used to describe the monofunctional nature of the mono-towns under review: in Monchegorsk (Murmansk region) $43.4 \%$ of the average number of working population are employed at Kola Mining and Metallurgical Company (Kola Encyclopaedia, 2013), and in Nikel respectively 39.1\% at Pechenganickel. Suffice it to say that $99 \%$ of Monchegorsk manufacturing sector output is produced by a single company.

Among the five outlined geo-economic risk categories - economic, geo-political, government economic policy, socio-demographic and spatial - the economic and socio-demographic categories are the most critical for the mono-town group under review (see Table 3).

In the economic category of geo-economic risks we shall explore such factors as the relation between global market developments and regional demand as well as economic relativities that consist in investment flow and import/export transaction influence, the monofunctionality and cyclical nature of global economy. The mono-towns under consideration are strongly exposed to these risks.

Global commodity market has a cyclical and volatile nature. Thus, in 1989 nickel cost over USD 18,000 per MT, whereas by 1999 the prices slumped below USD 4,000 and rose back to USD 16,000 in 2005. 
In the context of the crucial impact of global commodity market developments on transitional economies, the IMF conducted a survey of the key price cycle components related to the basic commodities in 1957-1999. According to this survey, aluminum went through seven complete price cycles. $58 \%$ of this period accounted for price recess and $42 \%$ to price growth. Price recess phase duration averaged 35 months with recess rate averaging 33\% (Cashin, McDermott, \& Scott, 1999). Such "pricing rallies" have a negative impact on socio-economic situation in mono-towns and dramatically increase geo-economic risk exposure of the respective operators. Sharp transition from growth phase to recess is especially critical. This factor constitutes a key problem in this sector of geo-economic risk management.

To this effect the economic relativity is reflected in excessive regression related to investment flows and export/import transactions. This implies high sensitivity of the operators (GMK Norilsky nickel, Fosagro, Eurochem and other geo-economic agents) from the market environment and demand. Global market risks can be classified as uncontrollable. These risks cannot be forecasted on a long-term basis as they are determined to a large extent by such factors as commodity consumption in China, technical progress, venture business ability to develop new sustainable technologies, major stock market speculations, public investment programs etc.

The cyclicity of global economy is primarily determined by the economic growth rate of the key material resource consumers (for Russia such consumers include EU, China, Turkey, Japan, Republic of Korea, and USA) and strength in the global market. To this effect the assessments of the commodity boom of the past decade made by Ruchir Sharma, head of Emerging Markets at Morgan Stanley Investment Management. Specifically, he has pointed out expressly that in the near term we may face a collapse of the commodity bubble generated by outrageous consumption in China and some other developing markets (Sharma, 2013).

However, this risk category includes another sub-category that jeopardizes oil and gas producing towns of Arctic Russia, i.e. retreat from the global market of this strategic commodity due to a number of developments in certain countries. Primarily this is related to the shale revolution in the US, which will enable this country from 2016 to start export of cheaper LPG to Europe, accelerated renewable energy efforts in Germany and other EU countries and expansion of Arctic hydrocarbon production by Norway, Iceland and Denmark. Furthermore, expansion of Turkmenistan's gas export to China and, under certain circumstances, to Europe, also needs to be taken into consideration. All these factors will have impact on the sustainability of the revenues of Russia's key oil and gas producers and, accordingly, sustainability of Russia's Arctic mono-towns.

It is also worth mentioning that market economy makes the development of effective diversification programs for mono-industry economies an extremely challenging task. It is not by accident that L. Carpov, a researcher of new development areas in advanced markets wrote in 1972: "The attempts to enhance economic sustainability of the new centers through integrated deployment of local resources, development of local manufacturing facilities and respective reduction of local economy dependence on mono-product market condition failed. This is not surprising. Generally the development of natural resources in new areas is governed by the law of value, and private business develop only the best part of natural resources, i.e. the part that offers fast earnings" (Carpov, 1971). Although he refers to Canada in this statement, it is quite relevant in the context of contemporary Russia.

Another challenge related to rehabilitation of mono-towns in contemporary Russia consists in the necessity to deploy market tools and regional economic policy methods in the environment of regional socio-economic systems established under planned economy. S. Kuznetsov points out: "Attempts have been made to overcome their dependence from local economic mainstays through SME promotion, yet as a rule the SME promotion programs were based on 'no-change' scenarios and did not achieve the main objective, i.e. creation of well-paid employment opportunities" (Kuznetsov, 2013).

In this context the Ministry of regional development on behalf of Russian government developed in 2009 an integrated investment planning (IIP) tool for mono-town recovery from crisis. According to the authors of this tool, "the primary objective of IIP consists in moving mono-towns from uncontrolled risk exposure to controlled risk exposure for creating an integrated upgrading environment and transition to diversified industry and sustainable socio-economic and environmental growth" (Guidelines). Yet for commodity export mono-towns this is a very challenging task.

In the socio-demographic subcategory of geo-economic risks the most critical are skill growth (loss) skill level risk combined with local depopulation risk as resulting from the effect of demographic and socio-economic factors. These risks are systemic and extremely disturbing in the context of mono-industrial economy and severe Arctic physiographic conditions.

In all Russia's European Arctic mono-towns the following tendencies can be recorded: population decline in 1989-2013 that ranges from $35.4 \%$ in Kirovsk to $51.1 \%$ in Inta induced by natural depopulation combined with 
mechanical out-migration; able-bodied population decline (65-68\%); average age increase; retired population growth (in average to 39\%). However, one of the key attributes of socio-demographic risk exposure of such towns consists in school graduate tendency to continue education in regional capitals, i.e. Murmansk, Petrozavodsk, Syktyvkar etc., or such federal cities as St. Petersburg and Moscow and continuing their careers there. This is especially indicative, since a Northern allowance system is applicable in Russia's European Arctic mono-towns.

At the same time, most Western Siberian towns feature positive socio-demographic indicators due to the stable socio-economic situation of the local operators (Gazprom).

Table 3. Geo-economic risk exposure of Russia's Arctic commodity export mono-towns

\begin{tabular}{|c|c|c|c|c|c|}
\hline \multirow{2}{*}{$\begin{array}{l}\text { Geo-economic } \\
\text { risk subcategory }\end{array}$} & \multirow[t]{2}{*}{ Geo-economic risk } & \multicolumn{2}{|c|}{$\begin{array}{l}\text { Geo-economic risk } \\
\text { mono-towns }\end{array}$} & \multicolumn{2}{|c|}{ exposure of industria } \\
\hline & & OGMT & MMT & CMMT & MMMT \\
\hline \multirow{2}{*}{$\begin{array}{l}\text { Globalization } \\
\text { (internationlization) }\end{array}$} & $\begin{array}{l}\text { Global market impact on fiscal } \\
\text { revenues; }\end{array}$ & +++ & ++ & ++++ & ++ \\
\hline & Monofunctionality; & ++++ & +++ & ++++ & +++ \\
\hline Economic relativity & $\begin{array}{l}\text { Excessive investment and export } \\
\text { dependence }\end{array}$ & +++ & ++++ & +++ & +++ \\
\hline \multirow[t]{5}{*}{$\begin{array}{l}\text { Global economy } \\
\text { cyclicity }\end{array}$} & Strategic commodity market loss & ++++ & ++ & +++ & ++ \\
\hline & $\begin{array}{l}\text { Social conflicts induced by wage } \\
\text { arrears and layoffs }\end{array}$ & ++ & +++ & ++++ & ++ \\
\hline & Further social differentiation; & ++ & ++ & +++ & +++ \\
\hline & Skill loss; & + & ++++ & ++++ & ++ \\
\hline & $\begin{array}{l}\text { Local depopulation due to effect of } \\
\text { demographic and socio-economic } \\
\text { factors }\end{array}$ & + & +++ & ++++ & +++ \\
\hline
\end{tabular}

OGMT - oil and gas mono-towns; MMMT - mineral mining mono-towns; CMMT - coal mining mono-towns; MMT - metallurgical mono-towns.

As follows from Table 3, the highest degree of geo-economic risk exposure is recorded for carbon and mineral mining mono-towns due to their relatively limited product range, i.e. nephelines, apatite products and hard coal.

Mono-industrial orientation of most Komi towns and communities results in their high unemployment risk exposure. In the 1990s lack of access to finance and improper utilization of the available resources, including World Bank loan, did not allow finding an efficient solution to the problem of excessive population in Inta, a depressive carbon-mining community, and today the expected local mine shutdown is leading to further aggravation of unemployment. This step requires relocation of over 3 thousand miners and their families, yet this expense item has not been budgeted by the government of the Republic (Social Atlas, 2009).

Another important social problem is related to partial elimination of Northern allowance in Komi Republic (in contrast to civil servant income indexation). Further review of the remaining numerous benefits and allowances is expected. All these steps lead to increasing social strain and barrier implementation of more effective earmarked social protection initiatives.

Oil and gas mono-towns (Noyabrsk, Nadym, Novy Urengoy and Gubkinsky) are less exposed to social risks due to sustained population growth and stable social environment. For example, the poverty rate in Yamalo-Nenets autonomous district has been one of the lowest in Russia since the 1990s. In 2009 it was 7.8\% (against 13.1\% average national rate). One of the key factors of mono-industrial economic risk exposure control consists in policy review of Gazprom, the local gas industry monopolist.

Thus, in 2009 the tax and non-tax revenues of Yamalo-Nenets autonomous district budget decreased insignificantly (by 4.4\%) in contrast to other advanced regions. Corporate income tax reduction (by $22 \%$ in 2009 
versus 2008) was overcome, and in 2010 it exceeded the 2008 nominal indicators by over one third. This means that Gazprom opted for paying the bulk of its income tax on the basis of tax residency of its production facilities in Yamal.

However, potential loss of European gas market positions, for example, due to Quatar and Norwegian expansion and US gas export, may change the situation and increase risk exposure of Yamal's prospering mono-towns.

\section{Conclusions}

We have performed a spatial study of geo-economic risk exposure of Russia's Arctic mono-towns with commodity export-based economy.

Russia's extreme dependence on the global commodity market trends has virtually no impact on the country's metropolitan cities, i.e. Moscow and St. Petersburg, as well as Moscow and Leningrad region metropolitan areas. These areas follow a post-industrial development path with a Russian accent.

However, such dependence is critical for mono-towns and their suburbs. The highest degree of geo-economic risk exposure is recorded for carbon and mineral mining mono-towns due to their relatively limited product range, i.e. nephelines, apatite products and hard coal.

The situation is further aggravated by impossibility to apply the North-American scenario of mono-industrial economy re-orientation which allows easy relocation of the population of such distressed communities due to favourable labour market, beneficial transport tariffs and advanced MSE sector. As noted above, the population of distressed communities is about 200 thousand people.

Besides, the national security and geo-political context of the existing Arctic mono-towns does not allow the use of traditional regional policy tools for the solution of these problems (Zabotin \& Latchininsky, 2008).

Therefore, geo-economic risk exposure reduction, specifically in terms of socio-demographic risks, requires an integrated approach to rehabilitation of Russia's Arctic mono-towns for urban environment improvement and investment promotion for local business community and MSE development.

\section{References}

Animitsa, E. G., Bochko, V. S., Peshina, E. V., \& Animitsa, P. E. (2010). Conceptual approaches to mono-town development policy framework planning. In A. I. Tatarkin \& M. V. Fedorov (Eds.), Urals st. econ. univ., RAS Inst. of Ural district economy.- Yekaterinburg: UrGEU. 81.

Artobolevsky, S. S., Baburin, V. L., Baklanov, P. Y., Kasimov, N. S., Kolosov, V. A., Kotlyakov, V. M., ... Tishkov, A. A. (2009). Spatial development policy strategies in the Russian Federation: geographic resources and constraints. In RAS Newsletter. Geographic series, 3, 8-17.

Cashin, P., McDermott, C., \& Scott, A. (1999). Booms and Slumps in World Commodity Prices. IMF working paper. Research department, IMF.

Depledge, D. (2013). What's in a name? A UK Arctic policy framework for 2013. The Geographical Journal, 179(4), 369-372. http://dx.doi.org/10.1111/geoj.12039

Guidelines for mono-town integrated rehabilitation investment plans. (2012). Retrieved from http://gov.cap.ru/home/24/oip/17.doc

Integrated mono-town rehabilitation investment plan for Monchegorsk, Murmansk region. (2013). Appendix to city government decree dated 06.02.2013 N164.

Karpov, L. N. (1971). New areas in advanced capitalist economies. Moscow, Mysl, 303.

Kola Encyclopaedia. (2013). Retrieved from http://kolaenc.gov-murman.ru/demography/population/

Kuznetsov S. V., Nikiforova L. Y. (2013). Integrated investment plans for Russia's Arctic mono-town rehabilitation. North and market economy: economic order development, 4(35), 8-14.

Lachininskii, S. S. (2013). Experience on the typology of geoeconomic risks. Geography and Natural Resources, 34(2), 111-117.

Pilyasov, A. N. (2011). Russia's Arctic regions development strategy outline. Arctic Region: ecology and economy, 1, 37-47.

Pilyasov, A. N. (2013). Russian Arctic region development and national security strategy until 2020. Retrieved from http://www.2010.forumstrategov.ru/upload/documents/ pilyasov.pdf

Sharma, R. (2013). Breakout Nations: In Pursuit of the Next Economic Miracles/Ruchir Sharma; translation 
from English by O. Medved. Moscow: Mann, Ivanov and Ferber. 352.

Social Atlas of Russian Regions. (2003). Retrieved from http://www.socpol.ru/atlas/portraits/komi.shtml

Zabotin, S. S., \& Latchininsky, S. S. (2008). Russian Arctic Sector: From Antagonisms to Collaboration. Challenges for oil and gas development in the Arctic, Tromco, 18-19

\section{Copyrights}

Copyright for this article is retained by the author(s), with first publication rights granted to the journal.

This is an open-access article distributed under the terms and conditions of the Creative Commons Attribution license (http://creativecommons.org/licenses/by/3.0/). 